\title{
NEOPROTEROZOIC WESTERN GONDWANA ASSEMBLY AND SUBDUCTION- RELATED PLUTONISM: THE ROLE OF THE RIO NEGRO COMPLEX IN THE RIBEIRA BELT
}

\section{MIGUEL TUPINAMBÁ ${ }^{1,2}$, WILSON TEIXEIRA ${ }^{2}$ AND MONICA HEILBRON ${ }^{1}$}

\begin{abstract}
The assembly of Western Gondwana, during the Neoproterozoic, involved the São Francisco/West Congo Craton and its passive margins. The Ribeira Belt lies along the Brazilian Atlantic Coast and is one of the products of the supercontinent amalgamation. Collisional processes were preceded by subduction, recorded by the Rio Negro Complex orthogneisses at the Ribeira Belt. Its plutonites represent a gabbrodiorite-tonalite-throndhjemite plutonic series that evolved from $637 \mathrm{Ma}$ (U-Pb zircon age of the tonalite gneiss) to nearly $600 \mathrm{Ma}$, at the beginning of the collisional event. Field, petrographic, litogeochemical, and isotopic characteristics of the Rio Negro Complex point to magmatism at a very mature oceanic arc or an immature continental crust as seen along attenuated passive margins. In the latter hypothesis, the margin could be related to a microplate or to the Congo/Angola Craton.
\end{abstract}

INTRODUCTION The São Francisco/West Congo Craton is surrounded by Brasiliano/Pan-African belts (720-550 Ma) that evolved during the agglutination of the Gondwana Supercontinent. The Ribeira Belt (Almeida et al. 1973), one of these belts, lies along the Brazilian Atlantic Coast (Fig. 1). This work deals with new geochemical and isotopic data on pre-collisional orthogneisses of the Rio Negro Complex belonging to the belt and the role of the magmatism in the tectonic evolution.

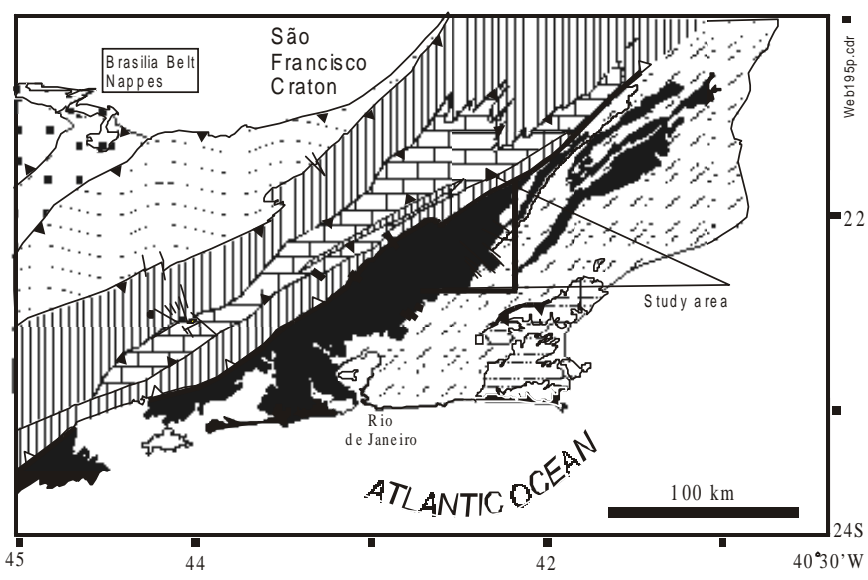

OCCIDENTAL TERRANE

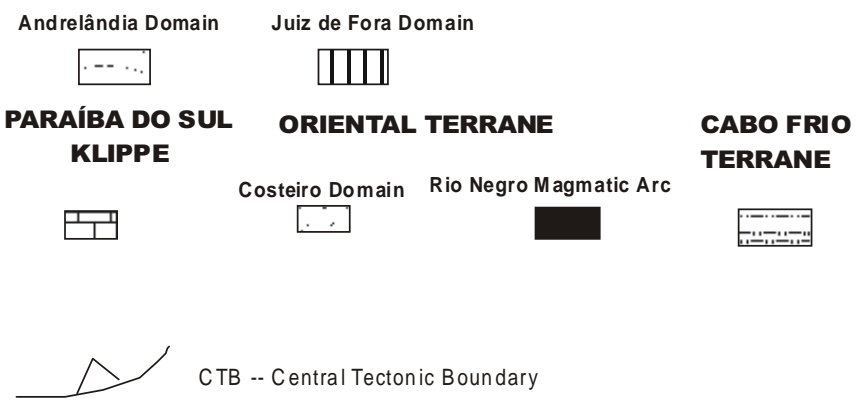

Figure 1-Tectonic map of the Central Ribeira Belt. Modified from Heilbron et al., 2000

TECTONIC SETTING The major tectonic framework of the $\mathrm{Ri}-$ beira Belt (Fig. 1) is defined by two distinct terranes (Heilbron et al. 2000). The Occidental Terrane comprises a pile of superposed allochtonous terranes thrusted to the west (Heilbron et al. 1995) and subsequently deformed in transpressional regime, with large vertical oblique shear zones associated with granitic plutons (Ebert et al. 1991). It is considered as the early São Francisco Craton passive margin (Heilbron et al. 2000). The Oriental Terrane (or Costeiro
Domain, Machado et al. 1996; Serra do Mar Microplate, Campos Neto and Figueiredo 1995) is characterized by large isoclinal recumbent folds, low angle dipping metamorphic foliation, and numerous NW trending ductile-ruptile shear zones containing post-collisional granitoids (Tupinambá 1999).

In the central segment of the Ribeira Belt (Fig. 1), the western edge of the Oriental Terrane is marked by a moderate northwest dipping $\left(\sim 35^{\circ}\right)$ shear zone - the Central Tectonic Boundary (Almeida et al. 1998). The Oriental Terrane was divided by Heilbron et al. (2000) into three tectono-magmatic domains: the Rio Negro Magmatic Arc and the Costeiro and Cabo Frio domains (Fig. 1).

The RNC (Rio Negro Complex, Tupinambá et al. 1996) comprises tonalitic to trondhjemitic orthogneisses, hornblende gabbro and quartz diorite stocks from subduction-related magmatism. Sin-collisional leucogranites with banded and homophonous textures crosscut the Rio Negro Complex orthogneisses (Tupinambá 1999). A megasheet of granodioritic to granitic orthogneiss (Serra dos Órgãos Batholith, Barbosa and Grossi Sad 1985) was emplaced during the sin- to latecollisional orogenic phase. Late to post-collisional non-foliated granite stocks and sills are also present (Junho 1990). The country rocks of the plutonites are high-grade metasediments of the Paraíba do Sul Group (Ebert 1968), comprising garnet-(cordierite)-(sillimanite)-biotite gneisses, quartzites, calc-silicate rocks and marbles. The studied area is located along the northern edge of the Rio Negro Magmatic Arc, which occupies $2 / 3$ of the area of the Oriental Terrane, almost $600-\mathrm{km}$ along the Atlantic Coast, from northern São Paulo to southern Espirito Santo (Fig.1).

The main deformation in the Oriental Terrane is characterized by: a) migmatitic and locally mylonitic foliation within the metasedimentary rocks; b) folding of this foliation by kilometer-scale recumbent folds with NW dipping axial plane and $\mathrm{N}$ trending axis; b) coarse grained foliation and discrete shear zones within the orthogneisses, parallel to the recumbent folds axial plane. Late deformation is represented by two sets of normal open to tight folds with NE and NW trending axis. Discrete vertical dipping transpressional and transtensional shear zones are also related to the late stage deformation.

The RNC orthogneisses were formerly considered as a Paleoproterozoic basement (Machado and Demange 1994). Published $\mathrm{Rb}-\mathrm{Sr}$ isochronic ages of granitoid gneisses from the Oriental Terrane similar to the RNC rocks are usually older than $600 \mathrm{Ma}$ (Fonseca et al. 1984, Batista and Kawashita 1985, Tassinari 1988, Dias Neto et al. 1995, Machado 1997). A leucogranite gneiss closely related to the Rio Negro Complex yielded a $620+/-20 \mathrm{Ma}$ concordant zircon age (Delhal et al. 1969, Tupinambá et al. 1997). In the northern Ribeira Belt, orthogneisses from the Rio Doce Magmatic arc (Figueiredo and Campos Neto 1993) yielded younger U-Pb zircon ages (590 to 570 Ma, Söllner at al 1991).

TONALITIC GNEISSES OF THE RIO NEGRO COMPLEX

The rocks of the Rio Negro complex were first described as stromatic or nebulitic migmatites and included in the Serra dos Órgãos Series (Rosier 1957), Santo Aleixo, Bingen (Penha et al.. 1979) and Rio Negro (Matos et al. 1980) units. However, the absence of melanosome or

1 - Faculdade de Geologia, Universidade Estadual do Rio de Janeiro (UERJ); Rua S. Francisco Xavier 524 sala A4006, Rio de Janeiro RJ Brazil 20559-900

2 - Instituto de Geociências, Universidade de São Paulo (USP) Rua do Lago 562 Cidade Universitária São Paulo SP CEP 05508-900 Brazil 
leucosome enrichments, the presence of igneous-looking textures and magmatic crosscutting led Tupinambá et al. (1996) to consider these rocks as a metaigneous complex.

The most widespread and representative rock of the complex is a coarse-grained hornblende bearing tonalite gneiss. Its gneissic fabric is due to planar aggregates of hornblende and biotite. These minerals, along with quartz and plagioclase (oligoclase), are the main constituents of the gneisses, whereas titanite and zircon are accessory mineral phases. Isolated poiquiloblastic crystals of hornblende and biotite, lobate contacts and anhedral quartz are interpreted as igneous minerals and textures. Subsequent dynamic metamorphic reactions produced aggregates of titanite, opaque minerals and tiny biotite flakes. Granoblastic textures including plagioclase, quartz and even hornblende may be also present. Layered sills and stocks of hornblende gabbro and gabbronorite, with hornblendite cumulates at the base and trondhjemite composition at the top, also occur within the Rio Negro Complex. Diorite and quartz diorite gneiss is associated with tonalite gneiss both in outcrop and map scales (Fig. 2).

RESULTS AND DISCUSSION Litogeochemistry Twentythree samples of gabbros, diorite, and tonalite from the RNC were collected near the cities of Nova Friburgo and Duas Barras (not shown in Fig. 1) and were analyzed at ACTLABS, Ontario, Canada. Table 1 contains major and selected trace element concentrations of tonalite gneiss samples.

The plutonic series is mainly tonalitic in composition but some sodic members are trondhjemitic in composition (Fig. 3a). The hornblende bearing metaluminous character is also clear (Fig. 3b). $\mathrm{Na}_{2} \mathrm{O}$ and $\mathrm{TiO}_{2}$ contents show positive correlation on Harker-type diagrams (some trends in Figure 3c); $\mathrm{FeO}$ (total), $\mathrm{MgO}, \mathrm{CaO}$ e $\mathrm{MnO}$ show negative correlation. $\mathrm{K}_{2} \mathrm{O}$ is almost constant between 1,5 and 2,0 $\%$, contrasting with high $\mathrm{CaO}$ concentration, that reaches almost $10 \%$. Similar chemical parameters were compiled by Barbarin (1999) to delineate typical subduction-related low K-high Ca calc-alkaline series $\left(\mathrm{H}_{\mathrm{CA}}\right.$ type). In a diagram using incompatible elements (Pearce et al. 1983), the samples plot in the volcanic arc field (Fig. 3d). In the R1x R2 diagram (Batchelor and Bowden, 1985) the RNC samples plot mainly within the pre-collisional field (Fig. 3e).

U/Pb zircon age We have obtained a $\mathrm{U}-\mathrm{Pb}$ zircon age from a 30 $\mathrm{kg}$ tonalite gneiss sampled in a quarry (20 $\left.30^{\prime} 42^{\prime \prime} \mathrm{S} ; 42^{\circ} 31^{\prime} 33^{\prime \prime} \mathrm{W}\right)$ located two kilometers NE of Duas Barras (not shown in Figure 1). Its typical zircon grains (5:1) are well crystallized and rich in rutile inclusions. Analyses of four zircon fractions with different magnetic properties were performed at CPGeo/USP (Table 2), which plotted in a concordia diagram (Fig. 4) yields an upper intercept age of $634 \pm 10$ Ma. This age is interpreted as the magmatic age of the tonalite.

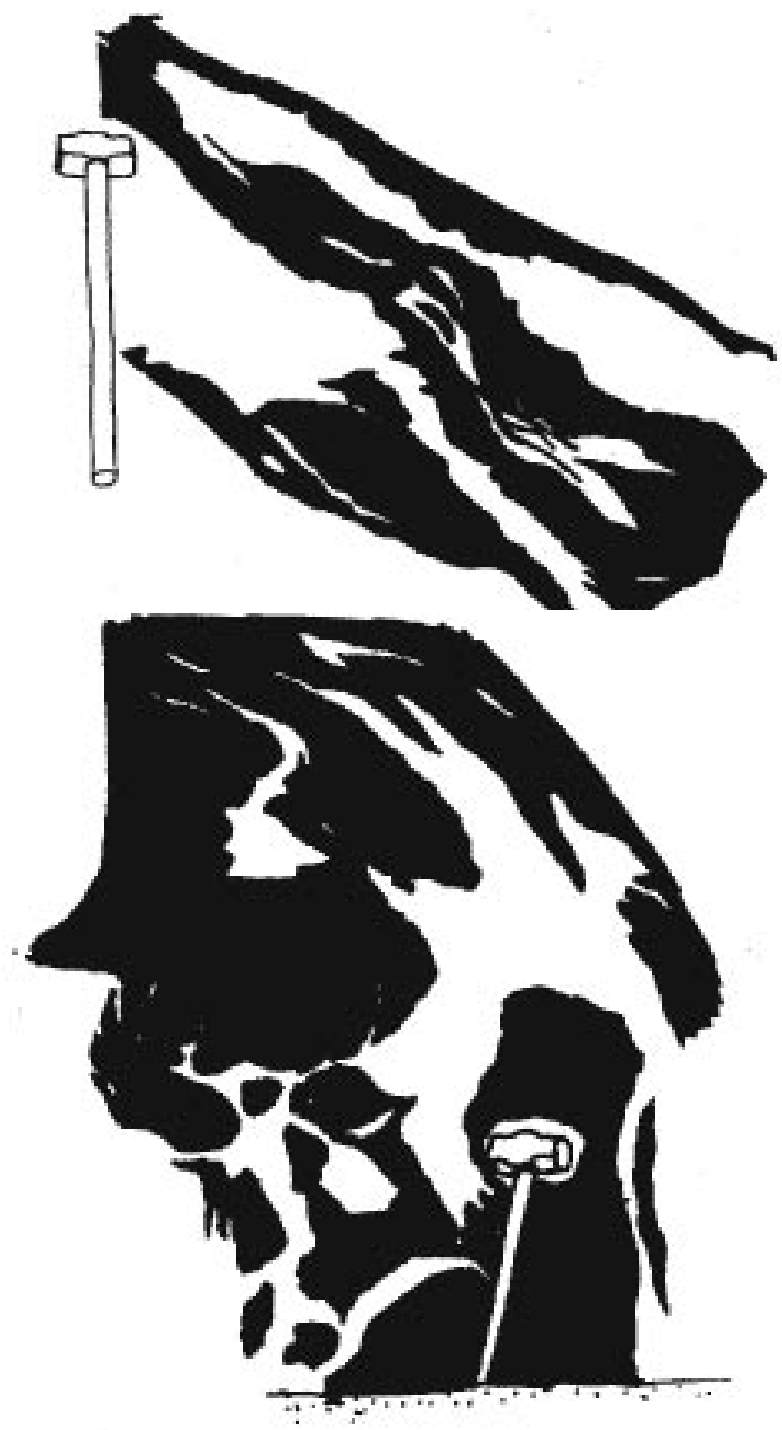

Figure 2-Field relations between tonalite gneiss (white) and diorite gneiss (black) of the Rio Negro Complex. The fields sketches show tonalite pods interlayered with diorite gneiss, oppositely, small irregular blocks and pods of diorite gneiss also occur within larger tonalite gneiss stocks.

Table 1-Chemical analytical data from tonalite gneiss of the Rio Negro Complex from Nova Friburgo, Duas Barras and Sumidouro.

\begin{tabular}{|c|c|c|c|c|c|c|c|}
\hline & DB-I-53 & DB-TUP-8o,r & DB-TUP-8m & CO-TUP-2E & DB-TUP-30D & DB-III-54 & DB-I-8 \\
\hline $\mathrm{SiO}_{2}$ & 54.42 & 54.76 & 66.23 & 61.93 & 62.10 & 68.98 & 75.76 \\
\hline $\mathrm{TiO}_{2}$ & 1.04 & 0.97 & 0.62 & 0.63 & 0.60 & 0.45 & 0.02 \\
\hline $\mathrm{Al}_{2} \mathrm{O}_{3}$ & 17.10 & 18.11 & 17.72 & 15.95 & 17.02 & 14.81 & 15.24 \\
\hline $\mathrm{FeO}^{*}$ & 8.69 & 6.54 & 2.80 & 5.29 & 5.34 & 3.04 & 0.45 \\
\hline $\mathrm{MnO}$ & 0.17 & 0.13 & 0.04 & 0.13 & 0.12 & 0.09 & 0.01 \\
\hline $\mathrm{MgO}$ & 3.84 & 3.44 & 1.65 & 2.34 & 2.53 & 0.86 & 0.06 \\
\hline $\mathrm{CaO}$ & 6.83 & 7.13 & 4.87 & 5.47 & 6.21 & 3.00 & 3.76 \\
\hline $\mathrm{Na}_{2} \mathrm{O}$ & 2.86 & 3.97 & 4.43 & 3.90 & 4.12 & 6.51 & 4.76 \\
\hline$\overline{\mathrm{K}_{2} \mathrm{O}}$ & 2.15 & 1.86 & 1.39 & 1.69 & 1.72 & 2.11 & 0.24 \\
\hline $\mathrm{P}_{2} \mathrm{O}_{5}$ & 0.30 & 0.32 & 0.22 & 0.17 & 0.17 & 0.15 & -0.01 \\
\hline LOI & 0.74 & 0.91 & 0.67 & 0.44 & 0.47 & 0.23 & 0.42 \\
\hline TOT & 98.14 & 98.14 & 100.64 & 97.94 & 100.4 & 100.23 & 100.71 \\
\hline $\mathrm{Rb}$ & 56 & 38 & 44 & 75 & 57 & 64 & 3 \\
\hline $\mathrm{Nb}$ & 8.5 & 5.1 & 17.0 & 18.7 & 7.0 & 6.0 & 2.0 \\
\hline $\mathrm{Y}$ & 23 & 36 & 6 & 68 & 24 & 26 & 3 \\
\hline
\end{tabular}

Analyses at ACTLABS, Ontario, Canadá. Concentration of major elements in \%. Minor and trace elements in ppm. 

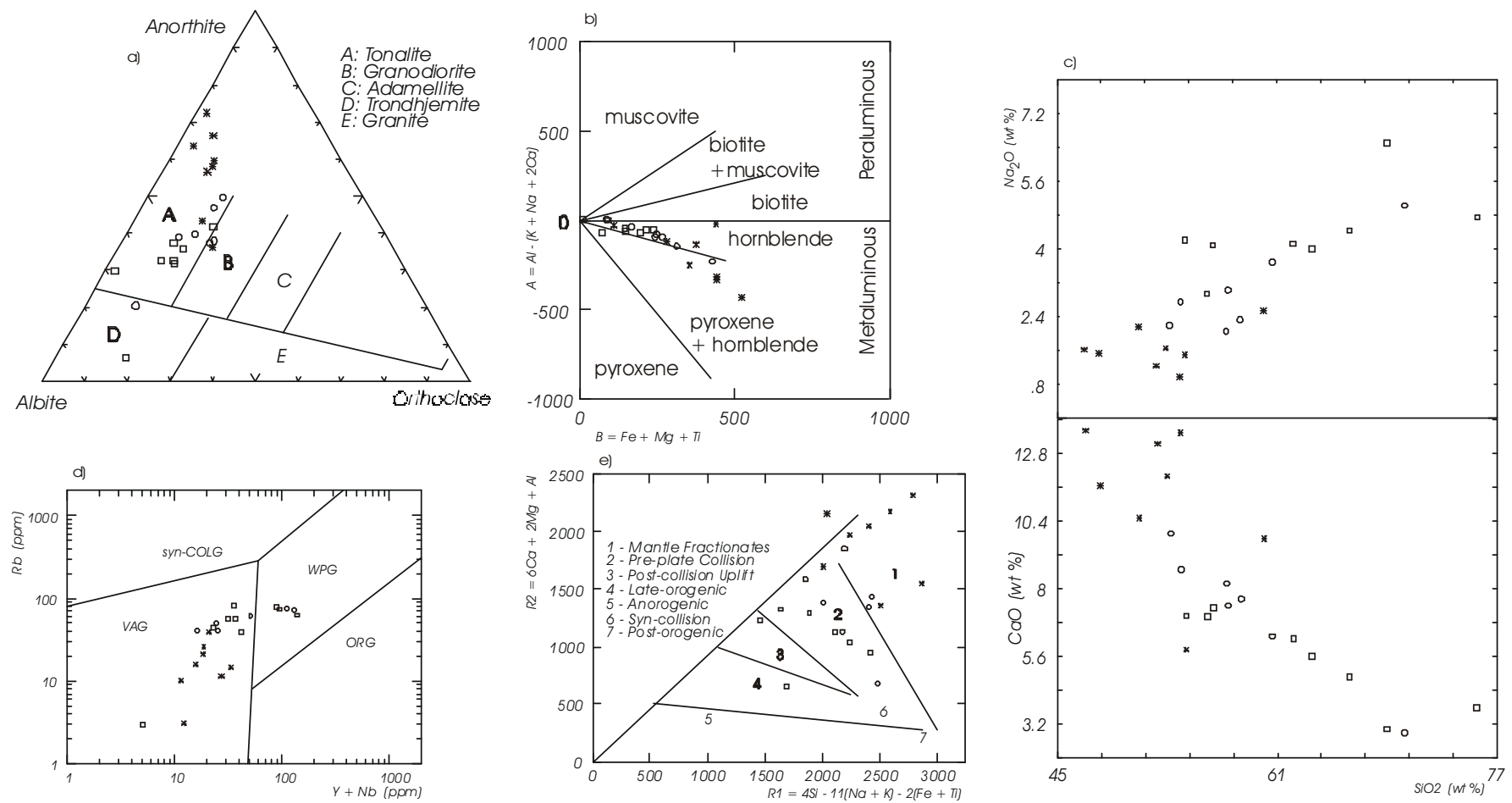

Figure 3-Litogeochemistry of the samples from the Rio Negro Complex. Asterisks: gabbro; circles: diorite to quartz diorite gneiss; squares: tonalite gneiss. A) tonalite to trondhjemite composition on a normative albite-anorthite-orthoclase triangular diagram; $b$ ) hornblende-bearing metaluminous character of the series (De Bon and Le Fort, 1980); c) Harker-type variation diagram for $\mathrm{Na}_{2} \mathrm{O}$ and $\mathrm{CaO} ; \mathrm{d}$ ) volcanic arc component of the samples in the trace-element diagram of Pearce et. al (1984); e) pre-collisional trend of non-cumulate rocks in the R1xR2 diagram of Batchelor and Bowden (1982)

Table 2-U-Pb analytical results from a tonalite gneiss (sample DB-TUP-30D).

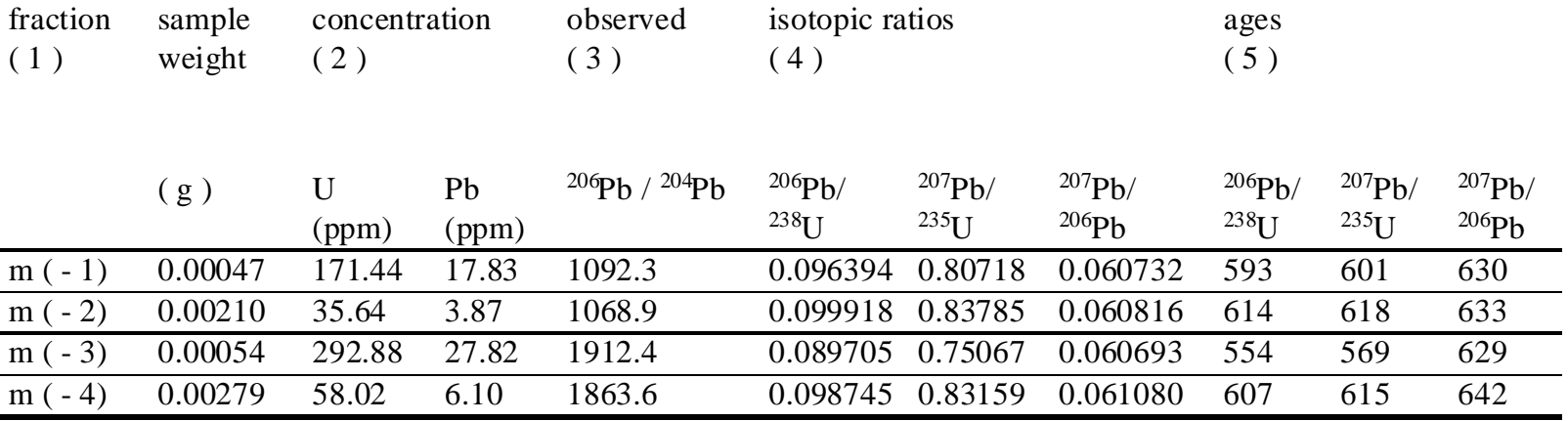

General analytical procedures of the CPGeo/USP in Basei et al. (1991). 1: $\mathrm{m}$ - magnetic fractions. numbers in parentheses indicated the tilt used on Frantz separator at $1.5 \mathrm{amp}$. current; all fractions contain prismatic. huge (5:1) and yellowish zircons with rutile inclusions. 2: Total $\mathrm{U}$ and $\mathrm{Pb}$ concentrations corrected for analytical blank; 3: Not corrected for blank or nonradiogenic $\mathrm{Pb}$; 4: Radiogenic $\mathrm{Pb}$ corrected for blank and initial $\mathrm{Pb}$; $\mathrm{U}$ corrected for blank; 5: Ages given in Ma using Ludwig's ISOPLOT program (1993).

Nd and $\mathrm{Sr}$ isotopic data Three $\mathrm{Nd}$ isotopic analyses were performed (Table 3 ). The more basic rocks yielded lower $\mathrm{e}_{\mathrm{Nd}} 630 \mathrm{Ma}$ values: -4 for hornblende gabbro and -5 for diorite gneiss; the tonalite gneiss sample yields the highest $\varepsilon_{\text {a }}$ value ever reported in Neoproterozoic igneous rocks at the Ribeira Belt: -1 . This difference is also reflected in the $\mathrm{T}_{\mathrm{Dm}}$ Model Ages, which are $1.8 \mathrm{Ga}$ for hornblende gabbro and diorite gneiss and $1.3 \mathrm{Ga}$ for the tonalite gneiss.

$\mathrm{Sr}$ isotopic ratios from the RNC (Table 4) range from 0.7045 (tonalite gneiss) to 0.7085 (diorite gneiss); the more basic is the rock the higher is its $\left({ }^{87} \mathrm{Sr} /{ }^{86} \mathrm{Sr}\right)_{630 \mathrm{Ma}}$ ratio. The ${ }^{87} \mathrm{Sr} /{ }^{86} \mathrm{Sr}$ heterogeneity is probably due to subsequent metamorphic and hydrothermal processes. The differential isotopic enrichment is reflected in the extremely high MSWD value $(\sim 690)$ of the seven points reference isochron, which yields an age of $656 \pm 5 \mathrm{Ma}$ and ${ }^{87} \mathrm{Sr} /{ }^{86} \mathrm{Sr}$ initial ratio of 0.7076 . The relatively high ${ }^{87} \mathrm{Sr} /{ }^{86} \mathrm{Sr}$ initial ratio is probably related to country-rock assimilation during transport and emplacement.

Tectonic implications The geochronological and geochemical data presented and the analyses of previously published data suggest that a Neoproterozoic magmatic arc was active at the Oriental Terrane of the Ribeira Belt during the pre-collisional phase of the BrasilianoPan African Orogeny. The collisional stage, which marks the end of subduction-related magmatism, is represented by an extensive crustal melting that led to leucogranite generation at $600 \mathrm{Ma}$ (Tupinambá 1999). Therefore, the evolutionary period of the arc (640 to $600 \mathrm{Ma})$ is not related to the Rio Doce Magmatic Arc (590-560 Ma, Campos Neto and Figueiredo 1995) but fits the same interval proposed for the pre-collisional phase of Brasiliano Orogeny in other mobile belts around São Francisco Craton (Brito Neves and Cordani 1991).

It is noteworthy that pre-collisional magmatic rocks are not known in the Occidental Terrane of the Ribeira Belt. It carries, instead, many 
Table 3-Sm-Nd whole rock analytical data.

\begin{tabular}{|c|c|c|c|c|c|c|c|c|c|c|}
\hline sample & rock & $\mathrm{Sm}$ (ppm) & $\begin{array}{l}\mathrm{Nd} \\
(\mathrm{ppm})\end{array}$ & $\begin{array}{l}{ }^{147} \mathrm{Sm} / \\
{ }^{144} \mathrm{Nd}\end{array}$ & error & $\begin{array}{l}{ }^{143} \mathrm{Nd} / \\
{ }^{144} \mathrm{Nd}\end{array}$ & error & $\begin{array}{l}\mathrm{T}_{\mathrm{DM}} \\
\text { DePaolo }\end{array}$ & $\varepsilon_{(0)}$ & $\varepsilon_{(630)}$ \\
\hline CO-TUP-7B & diorite gn & 7.791 & 33.347 & 0.1413 & 0.0005 & 0.512178 & 0.000044 & 1.8 & -9 & -5 \\
\hline DB-TUP-30D & tonalite gn & 4.224 & 19.335 & 0.1321 & 0.0004 & 0.512337 & 0.000037 & 1.3 & -6 & -1 \\
\hline DB-FR-34A & hbl gabbro & 6.430 & 26.955 & 0.1443 & 0.0005 & 0.512229 & 0.000040 & 1.8 & -8 & -4 \\
\hline
\end{tabular}

Analyses at CPGeo-USP, using isotope dilution. gn: gneiss; hbl: hornblende

Table 4-Rb-Sr whole rock analytical data.

\begin{tabular}{lllllllll}
\hline Sample & Rock & $\mathrm{Rb}(\mathrm{ppm})$ & $\mathrm{Sr}(\mathrm{ppm})$ & ${ }^{87} \mathrm{Rb} /{ }^{86} \mathrm{Sr}$ & error & ${ }^{87} \mathrm{Sr} /{ }^{86} \mathrm{Sr}$ & error & $\left({ }^{87} \mathrm{Sr} /{ }^{86} \mathrm{Sr}\right)_{630}$ \\
DB-TUP-8I & qtz diorite gn & 65.10 & 467.90 & 0.4030 & 0.0110 & 0.71047 & 0.00015 & 0.70685 \\
\hline DB-TUP-8F & qtz diorite gn & 56.90 & 535.50 & 0.3080 & 0.0090 & 0.70952 & 0.00014 & 0.70675 \\
\hline DB-TUP-80.r & tonalite gn & 43.43 & 736.08 & 0.1708 & 0.0023 & 0.70880 & 0.00008 & 0.70727 \\
\hline CO-TUP-2F & tonalite gn & 57.00 & 274.00 & 0.6020 & 0.0170 & 0.71346 & 0.00008 & 0.70805 \\
\hline DB-FR-34A & hbl gabbro & 11.20 & 423.62 & 0.0765 & 0.0007 & 0.70848 & 0.00001 & 0.70779 \\
\hline DB-TUP-30D & tonalite gn & 48.61 & 347.86 & 0.4045 & 0.0040 & 0.70927 & 0.00001 & 0.70564 \\
\hline CO-TUP-7B & diorite gn & 54.53 & 244.15 & 0.6468 & 0.0055 & 0.71438 & 0.00001 & 0.70857 \\
\hline
\end{tabular}

Analyses at CPGeo-USP, using isotope dilution. gn: gneiss; hbl: hornblende

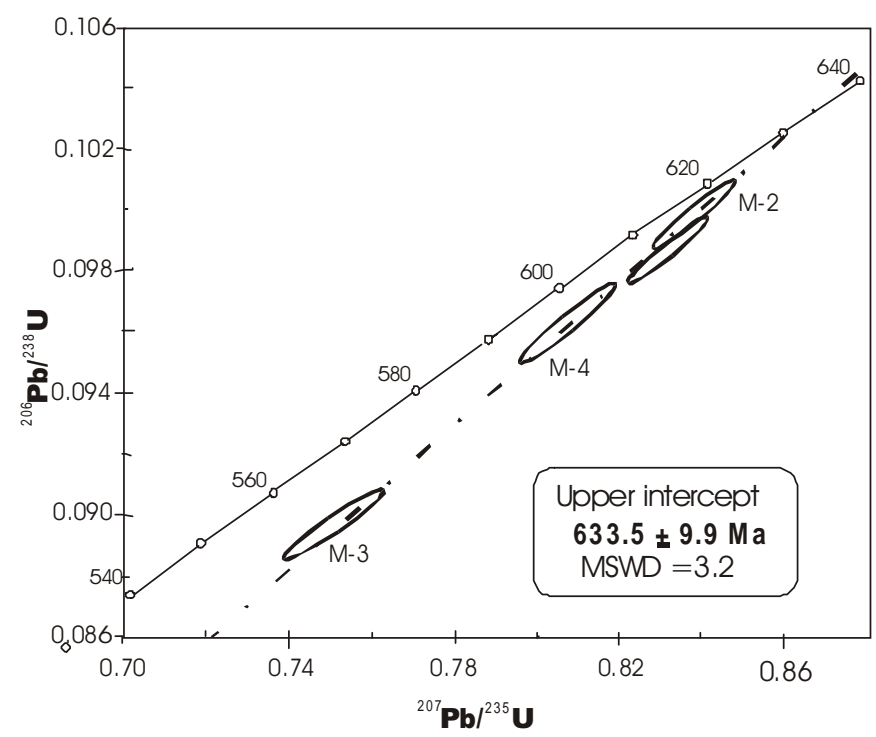

Figure 4-Concordia diagram, sample DB-Tup-30d. Analytical data in Table 2 sin- to late collisional granitoids. The existence of a magmatic arc at the Oriental Terrane brings new constraints on the palaeogeography of the Brasiliano/Panafrican orogeny. It implies that: a) during the Neoproterozoic assembly of Western Gondwana the closure of an oceanic basin produced the Rio Negro Magmatic Arc; b) the dip of the early subduction zone was to the East, in order to produce a magmatic arc only at the Oriental Terrane; c) the main phase of deformation and metamorphism in the central segment of the Ribeira Belt was caused by the collision of the São Francisco Craton passive margin (Occidental Terrane) with the Rio Negro Magmatic Arc and its country rocks (Oriental Terrane); d) the collisional suture, whether cryptical or not, is represented by the Central Tectonic Boundary (Figure 1).

The transitional isotopic and litogeochemical characteristics of the RNC plutonites lead to different genetic hypothesis: a) a plutonic basement of a very mature oceanic arc; b) a magmatism emplaced on thin continental crust along a passive margin. As the early subduction zone had its dip to the east, the passive margin of the later hypothesis could be the margin of a microplate (Serra do Mar Microplate (?), Campos Neto and Figueiredo 1995) or the West Congo / Angola Craton continental margin.

\section{Acknowledgements}

To FAPESP (grant 90.466/95) and FAPERJ (grant E-26/171.494/97) for financial support given to fieldwork, litogeochemical and isotopic analyses. To CNPq for doctoral grant (first author) and research grant (the other authors). To C. M. Valeriano, J. C. H. de Almeida and D. Ragatky (Tektos/UERJ) for field and laboratory support, to M. Brown (University of Maryland) and two RBG referees whom also contributed with many suggestions.

\section{References}

Almeida F.F.M. de, Amaral G., Cordani U., Kawashita K. 1973. The Precambrian evolution of the South American Cratonic Margin, South of Amazon River. In: Nairn \& Stelli (eds.) The ocean basin and margins, New York, Plenum, 1:411-416.

Almeida J.C.H., Tupinambá M., Heilbron M., Trow R. 1998. Geometric and kinematic analysis at the Central Tectonic Boundary of the Ribeira Belt, Southeastern Brazil. In: SBG, Congresso Brasileiro Geologia, 39, Belo Horizonte, Anais, 32.

Basei M. A. S., Siga Jr. O., Sato K., Sproesser M. 1995. A metodologia urânio-chumbo na Universidade de São Paulo. Princípios metodológicos, aplicações e resultados obtidos. An. Acad. Bras. Cien., 67: 221-237.

Barbarin B. 1999. A review of the relationships between granitoid types, their origins and their geodynamic environments. Lithos 46: 605-626.

Barbosa A.L.M. \& Grossi Sad J.H. 1985. Batólito granítico da Serra dos Órgãos, Estado do Rio de Janeiro, Brasil. Contrib. Geol. Petrol. Núcleo de Minas Gerais, SBGM, 1985:49-61.
Batchelor R.A. \& Bowden P. 1985. Petrogenetic interpretation of granitoid rock series using multicationic parameters, Chemical Geology 48:43-55.

Batista J.J \& Kawashita K. 1985. Contribuiçäo ao acervo geocronológico da porçäo setentrional do cinturäo Ribeira. In: SBG/SP Simp. Reg. Geol,, Atas, 1:187-200.

Brito Neves B.B. \& Cordani U.G. 1991. Tectonic Evolution of South America during the Late Proterozoic. Precambrian Research, 53: 23-40.

Campos Neto M.C. \& Figueiredo M.C.H. 1995. The Rio Doce Orogeny, Southeastern Brazil. J. South Am. Earth Sc., 8:143-162.

Delhal J., Ledent D., Cordani U.G. 1969. Ages $\mathrm{Pb} / \mathrm{U}$ et $\mathrm{Rb} / \mathrm{Sr}$ et $\mathrm{K} / \mathrm{Ar}$ de formations metamorphiques et granitiques de Sud-Est du Brésil (États de Rio de Janeiro et Minas Gerais). Ann. Soc. Géol. Bélg., T. 92: 271-283.

Dias Neto C.M., Tassinari C.C.G., Egydio Silva M. 1995. Idades Rb-Sr das rochas da região de Bananal - SP. Bol. IG-USP, Série Científica, 26: 59-68. 
Ebert H. 1968. Ocorrência da fácies granulítica no sul de Minas Gerais e em áreas adjacentes, em dependência de sua estrutura orogênica: Hipótese sobre sua origem. An.Acad. Bras.Cien., 40(supl):215-229.

Ebert H.D., Hasui Y., Sena Costa J.B. 1991. O caráter transpressivo do Cinturão Transcorrente Rio Paraíba do Sul. In SBG, Simpósio Nacional De Estudos Tectônicos, 3, Anais. 139-141

Figueiredo M.C.H. \& Campos Neto M.C. 1993. Geochemistry of the Rio Doce Magmatic Arc, Southeastern Brazil. An. Acad. Bras. Cien., 65(supl. 1):63-82.

Fonseca A.C., Cordani U.G. , Kawashita K. 1984. Dados preliminares sobre a geocronologia das rochas graníticas e suas encaixantes na cidade do Rio de Janeiro

ilbron M., Mohriak W. Valeriano, C.M., Milani, E.J., Alemida J., Tupinambá M. 2000 From collision to extension: the roots of the southeastern continental margin of Brazil. In: W. Mohriak, M. Talwani, (eds.): Atlantic Rifts and Continental Margins. American Geophysical Union Geophysical Monograph 115:1-31

Heilbron M.,Valeriano C.M., Valladares C., Machado N. 1995. A orogênese brasiliana no segmento central da Faixa Ribeira, Brasil. Rev. Bras.Geoc. 25: 249 - 266.

Junho M.C.B. 1990. Contribuição à petrologia dos maciços graníticos de Pedra Branca, Nova Friburgo e Frades ,RJ. PhD Thesis, IG/UFRJ, 172 p.

Machado R. 1997. Litogeoquímica e tectônica dos granitóides neoproterozóicos do Cinturão Paraíba do Sul no Estado do Rio de Janeiro. Inst. Geociências, USP, Tese de LivreDocência, 215 p.

Machado R. \& Demange M. 1994. Classificação estrutural e tectônica dos granitóides neoproterozóicos do Cinturão Paraíba do Sul no Estado do Rio de Janeiro. Bol. IGUSP, Série. Científica., 25: 81-96.

Machado N., Valladares C., Heilbron M., Valeriano C. 1996. U-Pb geochronology of the Central Ribeira Belt (Brazil) and implications for the evolution of the Brazilian Orogeny. Precambrian. Res., 79:347-361.

Mattos G.M.M., Ferrari P.G., Cavalcante J.C. 1980. Projeto faixa calcária Cordeiro Cantagalo. Rel. Final, texto e mapas geológicos, vol. I. CPRM, Belo Horizonte, 620 p.
Pearce J.A., Harris M.B.W., Tindle A.G. 1984. Trace element discrimination diagrams for the tectonic interpretation of granitic rocks. J. Petrol., 25:956-983

Penha H.M., Ferrari A.L., Riveiro A., Amador E.S., Pentagna F.V., Junho M.C.B., Brenner T.L. 1979. Projeto Folha Petrópolis, Rel. Final, vol. I. Proj. carta geológica do Estado do RJ, DRM/IG-UFRJ, $256 \mathrm{p}$.

Rosier G.F. 1957. A geologia da Serra do Mar, entre os picos de Maria Comprida e do Desengano (Estado do Rio de Janeiro). Bol DGM/DNPM, 222

Söllner F., Lammerer B., Weber-Diefenbach K. 1991. Die krustenentwicklung in der Küstenregion nordlich von Rio de Janeiro/Brasilien. Münchner Geol. Hefte, 4:101

p.
Tassinari C.C.G. 1988. As idades das rochas e dos eventos metamórficos da porção sudeste do Estado de São Paulo e sua evolução crustal. Instituto de Geociências, USP, PhD do Estado de S A

Tupinambá M. 1999 . Evolução tectônica e magmática da Faixa Ribeira na região serrana do Estado do Rio de Janeiro. Instituto de Geociências, USP. Ph.D. Thesis, 221p.

Tupinambá M., Heilbron M., Oliveira A., Pereira A.J., Cunha E.R.S.P, Fernandes G.A., Ferreira J, Castilho G., Teixeira W. 1996. Complexo Rio Negro - uma unidade estratigráfica relevante no entendimento da evolução da Faixa Ribeira. In: SBG, Congresso Brasileiro de Geologia, 39, 6:104-106.

Tupinambá M., Teixeira W., Duarte B.P., Heilbron M. 1997. U.G. Cordani \& J. Delhal's geochronological data from the Ribeira Belt revisited after thirty years. In: SouthAmerican Symposium on Isotope Geology, Campos do Jordão, Extended Abstracts, 320-322.

Contribution IGC - 012 Received February 2, 2000
Accepted for publication April 30, 2000 